\title{
Cell-to-cell movement of three genera (+) ss RNA plant viruses
}

\author{
Katarzyna Otulak • Grażyna Garbaczewska
}

Received: 24 June 2009/Revised: 1 May 2010/Accepted: 24 May 2010 / Published online: 12 June 2010

(C) The Author(s) 2010. This article is published with open access at Springerlink.com

\begin{abstract}
The current investigations of three genera plant virus cell-to-cell movement were presented. Viruses reveal different local transport strategies, but all of them are the results of virus factors-host components interactions. The Tobacco mosaic virus (TMV) does not require capsid protein for translocation through plasmodesmata but $30 \mathrm{~K}$ movement protein participates in this process. It was found direct or indirect TMV movement proteins host partners in Tobamovirus movement like: pectin methylesterase, movement protein binding $2 \mathrm{C}$, chaperones or cytoskeleton components and endoplasmatic reticulum membranes. The Potex- and Potyvirus cell-to-cell movement is closely related to replication network. The PVX capsid protein and triple gene block protein system are responsible for efficient local transport. Potyviruses move through the plasmodesmata by involving viral encoded proteins but not specific movement proteins. While the Potyvirus is the biggest known plant virus genus, host components participating in or regulating directly its plasmodesmata-movement are still not clear.
\end{abstract}

Keywords Cell-to-cell movement - Transport . Plasmodesmata - Tobamovirus · Tobacco mosaic virus. Potexvirus · Triple gene block · Potyvirus

Communicated by A. Kononowicz.

K. Otulak $(\bowtie) \cdot$ G. Garbaczewska Department of Botany, Faculty of Agriculture and Biology,

Warsaw University of Life Sciences-SGGW,

Nowoursynowska 166, 02-776 Warsaw, Poland

e-mail: katarzyna_otulak@sggw.pl

$\begin{array}{ll}\text { Abbreviations } & \\ \text { CI } & \begin{array}{l}\text { Cytoplasmic inclusion protein, Potyvirus } \\ \text { helicase }\end{array} \\ \text { CP } & \text { Capsid protein } \\ \text { CRT } & \text { Calreticulin } \\ \text { eIF4E, eIF4G } & \text { Eukaryotic translation factors } \\ \text { ER } & \text { Endoplasmatic reticulum } \\ \text { ERdt } & \text { Endoplasmatic reticulum desmotubule } \\ \text { M complex } & \text { Movement complex } \\ \text { ML } & \text { Middle lamela } \\ \text { MP } & \text { Movement protein } \\ \text { Mt } & \text { Microtubules } \\ \text { MPB2C } & \text { Movement protein binding 2C } \\ \text { NCAP } & \text { Non-cell autonomous protein } \\ \text { NTR } & \text { Non-translated region } \\ \text { ORF } & \text { Open reading frame } \\ \text { PD } & \text { Plasmodesmata } \\ \text { PM } & \text { Plasma membrane } \\ \text { PME } & \text { Pectin methylesterase } \\ \text { PVX } & \text { Potato virus } X \\ \text { PVY } & \text { Potato virus } Y \\ \text { RNP } & \text { Ribonucleoprotein complex } \\ \text { SEL } & \text { Size exclusion limit } \\ \text { STP } & \text { Single-tailed particles } \\ \text { TGB } & \text { Triple gene block } \\ \text { TMV } & \text { Tobacco mosaic virus } \\ \text { vs } & \text { Vesicle } \\ & \end{array}$

\section{Introduction}

The basis for effective virus infection in host-plants tissues is the replication of pathogen genetic material. Infection 
spreads due to two-phase virus transport process. The initial stage is the transport from the place of inoculation to neighboring cells, which is called local or cell-to-cell transport (Oparka 2004). In the second stage called longdistance or systemic transport (van Bel 2003), the pathogen penetrates inside vascular tissues and transports to uninfected cells. Irrespective of virus genus, the two mentioned types of transport require activation of two "agents"-host proteins and virus components.

In plant tissues cell-to-cell communication is possible due to plasmodesmata (PD). PD specific ultrastructure and size exclusion limit (SEL) were well described (Ding et al. 1992; Lucas 2006), but PD molecular composition is still unclear and its potential components remain under investigation (Waigmann et al. 2004). SEL limited to $1 \mathrm{kDa}$ is a barrier for the pathogen effective translocation to neighboring cells. There are two strategies of transporting through PD - the virus spreads as a particle or viral genetic material is transported in the form of ribonucleoprotein complexes (RNP). The process consists of three events:

1. Interaction between potential docking complex and PD,

2. Induction of PD microchannel increasing,

3. Fixation of inner translocation system in adjacent cell cytoplasm.

What is indispensable in these events, irrespective of virus group, is protein or virus protein which participates in transport-movement protein (MP) (Lucas and Lee 2004; Verchot-Lubicz 2005; Chen and Kim 2006; Lucas 2006). MPs are able to "mediate" in protein and vRNP translocation across PDs (Lucas et al. 1993). Numerous studies show that macrocomplexes movement follows the control pattern characteristic for non-cell autonomous protein (NCAP) molecules (Lucas 1995; Haywood et al. 2002). Detailed studies of RNA plant virus local transport mechanisms took place in the '90s. The subject of MP proteins/ host-plant components interaction remains under extensive study and is very much up-to-date, also due to new information on proteins constituting PD complex and on relation between cellular structures and PD in translocation process.

The object of this paper is to present the strategies of cell-to-cell movement of three genera (+) ss RNA plant viruses:

1. Model genus Tobamovirus, represented by Tobacco mosaic virus (TMV),

2. Potexvirus, coding characteristic sequences TGB [Potato virus X (PVX)],

3. The largest genus Potyvirus, represented by Potato virus $Y$ (PVY).

\section{Tobamovirus MP: Family 30 K Proteins}

Tobacco mosaic virus can move through PD in the form of virions, which was confirmed in the studies by Esau and Cronshaw (1967), Gibbs (1976), Weintraub et al. (1976). $30 \mathrm{kDa}$ protein, which enables TMV cell-to-cell transport, was identified as interacting with PD components. Also it was stated that in the presence of MP TMV, PD molecular size exclusion limit (SEL) increases from $1 \mathrm{kDa}$ to ca $10 \mathrm{kDa}$ in tobacco transgenic lines, where $30 \mathrm{kDa}$ protein expressions took place (Wolf et al. 1989). The family $30 \mathrm{k}$ proteins is the largest group of viral movement protein. They are characterized by weak sequence resemblance but they have one conservative motive $\mathrm{LXDX}_{50-70} \mathrm{G}$ (Koonin et al. 1991). Secondary structure analysis showed that the core region is build from $4 \alpha$-helis $(\alpha-\mathrm{A}-\mathrm{D})$ and 7 $\beta$-structures ( $\beta$-1-7). MP TMV core region is surrounded by two domains binding single-stranded nucleic acid (Citovsky et al. 1992) and domain engaged in PD SEL increase (Boyko et al. 2000). It is claimed that the C-terminal region is a regulating agent for the functional domains. The experiments conducted by Waigmann et al. (2000) and Citovsky and Zambryski (1993) proved that in the MP TMV C-terminal area are located three phosphorylation sites, which regulate MP biological activity. Studies by Brill et al. (2000) showed that two MP regions are resistant to digestion by trypsin and they contain two highly hydrophobic domains between 58 and 85 amino acid residues as well as 145 and 175. Such characteristic of two MP TMV domains enables us to categorize this protein as integral membrane protein (Reichel et al. 1999). The MP TMV C-terminal area from 250 to 268 amino acid residues was highly sensitive to trypsin treatment. In view of that it was shown that two MP TMV potential transmembrane domains "spin" the membrane to form U-shaped protein conformation while the $\mathrm{N}$ - and C-terminal regions are exposed to cytosol ( $\mathrm{N}_{\mathrm{cyt}}-\mathrm{C}_{\mathrm{cyt}}$ topology) (Brill et al. 2000).

\section{MP TMV and its partners in movement}

Direct transport of the virus genome from infected to neighboring healthy cells is realized through binding MP protein with virus nucleic acid and moving of this complex through PD. MP TMV was the first movement protein that showed binding with single-stranded (ss) RNA or DNA (Citovsky et al. 1990). Complexes of MP TMV-nucleic acid are estimated to measure $1.5-3.5 \mathrm{~nm}$ in diameter, which is compatible with 3.2-4.3 nm SEL-broadened PD (Waigmann et al. 1994; Kiseylova et al. 2001). The MP TMV mutation analysis indicated that activity of nucleic acid single strand is present in domains between amino acid radical 112-185 and 186-268 movement protein 
(Citovsky et al. 1992). The MP TMV binding to nucleic acid is not restricted only to specific nucleotide sequences (Atabekov et al. 1999). However, it was not proved how the tobacco mosaic virus MP locates virus RNA in an infected cell. It was suggested that MP with very strong affinity to single-stranded nucleic acid attaches to any ss RNA or ss DNA. It should be stressed that TMV replication and TMV proteins translation partly overlap "viral factories", which is why it is highly probable that MP TMV may easily acquire RNA TMV immediately during synthesis de novo (Heinlein et al. 1998; Brill et al. 2000). It was claimed that MP TMV forms complexes with endogenous cellular RNA during expression in bacterial cells. RNA TMV forms ribonucleoprotein complexes (vRNP) in infected plant cells. MP-virus genome complexes form usually during advanced transport process - they are called M-complex (movement complex). In this manner, the virus genome in the form of both RNA and DNA is protected against host cells' nucleases and creates a system, which facilitates the transfer and is compatible with PD transfer function (Kiseloyva et al. 2001). The M-complex formation of MP TMV and RNA TMV in vitro is non-replicating and non-translating in in vitro conditions and isolated protoplasts. Such inhibition suggests that M-complexes are partly non-capsidated during transfer across PD (Karpova et al. 1997). Such decapsidation may take place during the phosphorylation of MP TMV by protein kinases connected to the cell wall (Karpova et al. 1999).

During infection, pathogens adapt host cellular processes to their needs. MP proteins "build in" cell-to-cell transports pathways so that the virus can effectively spread its genome. While MP biological activity is scrutinized and relatively well known, MP partners in host-plant have not been fully examined yet. Also in this area, TMV gives us the most data. MP TMV is the first movement protein for which several interacting host proteins were isolated and identified. MP TMV cooperates with $38 \mathrm{kDa}$ cell wall protein isolated from tobacco leaves. On the basis of sequence analysis it was stated that it is cell wall pectin methylesterase (PME) (Dorokhov et al. 1999; Chen et al. 2000). The mechanism adopted for PME participation in TMV cell-to-cell transfer still remains unclear. One possibility is that PME plays the role of plant cell receptor to MP TMV (Dorokhov et al. 1999). PME immunolocalization in tobacco tissues indicated the presence of this protein in cell wall also in PD (Chen et al. 2000). Due to PME binding, MP TMV is docked to the host cell wall, if it takes place near PD, the movement is initiated. In case when binding PME to the cell wall is found in an area without PD, the movement is blocked and MP TMV is degraded or transferred to cytoplasm. PME may also participate in MP TMV transport to host plant ER. MP use ER membranes to transport from the place of synthesis to PD (Heinlein et al.
1998), where ER is also present. TMV movement proteins may be transferred to ER with the use of PME due to translocation signal to ER (Gaffe et al. 1997). According to these analyses, PME molecules may bind ER membranes, which is why they are able to interact with MP TMV and attach them to ER from the cytoplasm while conducting the transport to the cell wall. PME can be activated when MP TMV is accumulated beside the cell wall.

The concept assuming active participation of ER membranes in TMV cell-to-cell transport is called ER sliding model (Guenoune-Gelbart et al. 2008). It is suggested that newly synthesized MP TMV is incorporated into ER membranes and binds replicated (+) ss vRNA (Fig. 1). What is formed is a complex connected to endomembranes, which may also trigger virus replication-the forming of a replication complex (Asurmendi et al. 2004). In line with the given assumptions, MP can either directly or indirectly change properties of the wall surrounding PD, which can lead to PD broadening. Possibly it is connected with transport to ER with the use of cytoskeleton or ER vesicles which contains MP-vRNA complex moving across PD (Kawakami et al. 2004; Boevink and Oparka 2005; Lin et al. 2005; Wright et al. 2007, Sambade et al. 2009). When MP is not present, PD ER is stationary (Heinlein and Epel 2004). If MP is incorporated in ER, cell-to-cell transport takes place via MP-vRNA complex diffusion to PD desmotubules lipid matrix under the action of concentration gradient between healthy and infected cells (LippincottSchwartz et al. 2000; Runions et al. 2006). The MP presence in ER or in ER vesicles as well as the relation with microtubules (Heinlein et al. 1995) and microfilaments (McLean et al. 1995) suggests that elements of the cytoskeleton are an important component engaged in the transport to PD and in cell-to-cell movement of the viral ribonucleic complex (Mitra et al. 2003). Actins and myosins are present inside PD and are responsible for the ER membrane translocation (Blackman and Overall 1998; Yokota et al. 2009). Gillespie et al. (2002) and Heinlein and Epel (2004) postulated that PD broadening in induced MP may enable an active transport of vesicles from ER (with MP-vRNA) due to microfilaments. It was estimated that cell-to-cell transport of the vesicles (with virus complex) with the cytoskeleton involved in I-stage infection cells reaches $160 \mathrm{~nm} / \mathrm{s}$ (Kawakami et al. 2004). The movement of the viral replication complex from the place of I-stage infection to adjacent cells is spotted within $20 \mathrm{~h}$, whereas from the place of II-stage infection to adjacent cells within $4 \mathrm{~h}$ (Kawakami et al. 2004). Similar effects were noticed in MP TMV (MP:GFP) movement-observed after around $24 \mathrm{~h}$ after the construct injection.

Guenoune-Gelbart et al. (2008) updated TMV cell-tocell movement model. During initial stages of infection, the plant reacts by accumulating callose and $\mathrm{PD}$ blocking 
Fig. 1 Tobacco mosaic virus cell-to-cell movement. TMV MP binds and incorporates in ER and it binds vRNA. Replication and MP function synergistically by providing $\beta$-1,3-glucanase to the cell wal near PD. The $\beta$-1,3-glucanase limits callose accumulation near PD. The MP-vRNA-replication complexes diffuse into ERdesmotubule membranes. Cytoskeleton participate in TMV MP-vesicles movement to ER in PD. The MPB2C is a receptor in TMV MP transfer from ER to cytoskeleton triggering. Calcium binding protein-localized in PDcalreticulin is also engaged in TMV transport between ER and PD

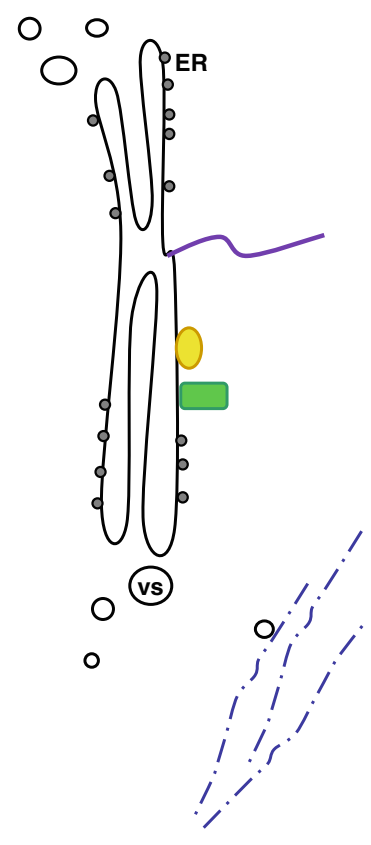

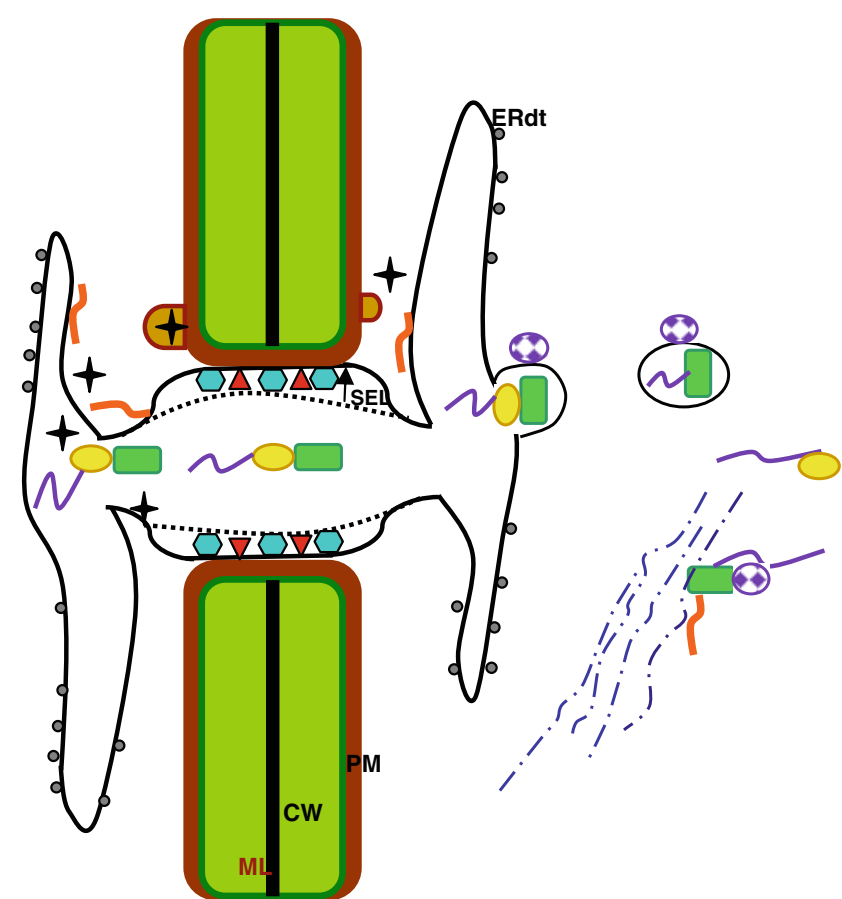

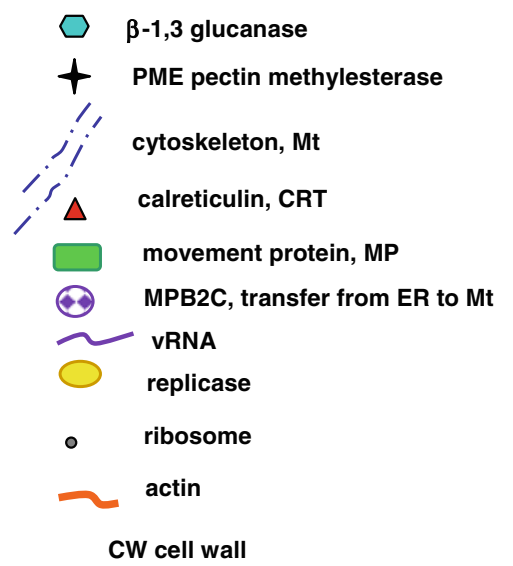

ML middle lamela

PM plasma membrane

vs vesicle

ER dt endoplasmatic reticulum desmotubule

MP/vRNP particles trafficking is rather mediated by ER (primarily) than involved in direct interaction with actin filaments. The PD-targeted MP transport and associated viral RNA occurs by diffusion in the ER membranes. The actin-myosin system with actin-binding factors may control this pathway. This system is able to support or slow down the transport of membrane-embedded protein complexes.

Tagami and Watanabe (2007) showed that secretive pathway/track ER-Golgi apparatus is rather not involved in supplying VRC (viral replicating complex) to PD or in 
virus cell-to-cell movement. Replication and MP function synergistically possibly by providing $\beta$-1,3-glucanase I-class to the cell wall near PD (due to ER vesicles) (Fridborg et al. 2003). I-class $\beta$-1,3-glucanase limits callose accumulation near PD which is induced by viral infection due to the diffusion of MP-vRNA-replication complex in ER-desmotubules membranes (Fig. 1) (Gillespie et al. 2002; Kawakami et al. 2004; Liu et al. 2005). GuenouneGelbart et al. (2008) suggested that the cytoskeleton is not directly involved. It functions as ER stabilizing factor (Heinlein et al. 1998) or it makes ER vesicles with $\beta$-1,3glucanase reach the cell wall near PD (Fridborg et al. 2003). Components of the cytoskeleton have their share in cell-to-cell movement of vesicles with MP to ER in PD (Oparka 2004).

Stressed was an indirect role in cell-to-cell transport not only of the cytoskeleton but also of the proteins cooperating with the cytoskeleton. Kragler et al. (2003) stressed the specific interaction between MP TMV and microtubule associated protein in tobacco tissues-MPB2C (movement protein binding $2 \mathrm{C}$ ). This endogenous plant agent may play a role of a negative effector in MP TMV cell-to-cell movement (Gillespie et al. 2002). Waigmann et al. (2004) postulated only indirect involvement of MPB2C in TMV cell-to-cell transport. They concluded that the protein might participate in the late stages of TMV infection, which could take place in the area right behind the front face of the spreading infection. The interaction with MPB2C may be induced in order to eliminate MP from host-cell cytoplasm. Potentially, MPB2C can be a receptor, which triggers MP transfer from ER to microtubules where MP forms stable complexes (Boyko et al. 2000). Curin et al. (2007) claimed that over-expression of MPB2C in $N$. benthamiana plants caused changes in MP-TMV location because of redistribution from PD to microtubules. In plants in which MPB2C was suppressed, the presence of microtubules associated MP-TMV was highly reduced and the presence of MP TMV near PD was increased as compared with unmodified plants. It was postulated that MPB2C might act as a decisive factor, which determines the balance between PD and TMV-MP microtubular location. Perhaps TMV-MP/MPB2C interaction is regulated during the infection spread as MP TMV microtubular accumulation is controlled in time and space. Host agent, MPB2C is not vital for TMV cell-to-cell movement or for systemic spreading. It is only needed for effective accumulation of TMV-MP in microtubules and it determines the subcellular location of TMV-MP.

What was also underlined was the involvement of host cell proteins of the type chaperones in TMV cell-to-cell movement. Chen et al. (2005) suggested calreticulin engagement in TMV translocation between ER and PD. Calreticulin is a protein, which was localized in PD due to
N-terminal signal peptide (Baluska et al. 1999; Michalak et al. 1999). Chen et al. (2005) showed that calreticulin interacts with TMV MP and over-expression of this protein in transgenic plants determines TMV relocation from PD to microtubules and thus cell-to-cell transport of the virus. Potential role of calreticulin in PD capacity was discussed also by Boevink and Oparka (2005), who underlined the ability of PD to modify thanks to MP TMV-CRT cooperation by changes in cell wall structure.

\section{Potexvirus cell-to-cell movement determinants}

Unlike Tobamovirus, members of Potexvirus genera need capsid protein for cell-to-cell transport the role of MP is filled by three types of proteins encoded by virus RNA. On the basis of these properties, Scholthof (2004) classified this type of plant virus transport to the so-called Type II (see Table 1). Potexvirus have single-stranded (+) ss RNA coding 5 open reading frame (ORF) (Verchot-Lubicz et al. 2007). First ORF codes viral replication, central region is made up from three overlapping ORFs known as triple gene block (TGB). Proteins coded by TGB transcripts are required for cell-to-cell transport (Verchot-Lubicz 2005). Final ORF is virus capsid protein, engaged not only in assembling the particles but also in cell-to-cell transport (Huisman et al. 1988; Santa Cruz et al. 1998).

Potexvirus code two proteins associated with ER: TGBp2 and TGBp3 (Mitra et al. 2003; Ju et al. 2005). They are the core of the movement process and so far no direct connection with replication process has been found. Two structures RNA stem-loop 5'SL1 and 5'SL2 are necessary for PVX replication (Miller et al. 1998, 1999). 5'SL1 is a multifunctional element, involved in virus replication, cellto-cell transport and virions assembling. Host proteins may identify $5^{\prime}$ SL1 by capsidation of viral particles, they can promote translation of replication of genome RNA (Kwon et al. 2005). A series of deletion mutation was used to

Table 1 Plant viruses classiffication based on movement proteins types according to Scholthof (2004) with modifications

\begin{tabular}{llll}
\hline Classification & Coat protein & Number of MPs & Example \\
\hline TYPE I & Not required & 1 & Tobamovirus \\
& & 2 & Carmovirus \\
TYPE II & Required & 1 & Hordeivirus \\
& & 2 & Cucumovirus \\
& & 3 & Potyvirus \\
& & $1-2$ & Potexvirus \\
TYPE III & Particles & 1 and tubules & Comovinivirus \\
& & $3-4$ (and 2CPs) & Closterovirus \\
\hline
\end{tabular}


identify a segment of RNA responsible for cell-to-cell movement of PVX. Deletion in the first $107 \mathrm{nt}$ of PVX genome (on $5^{\prime} \mathrm{SL} 1$ ) eliminated the movement of this pathogen, which showed that $5^{\prime} \mathrm{NTR}$ (non-translated region) is an element engaged in both transport and replication (Lough et al. 2006). In case of Potexvirus there is subgenome synthesis of RNA, CP may bind to 5'SL1, moving the host agent. Capsid protein is needed for cell-tocell transport as this region hides RNA from virus replication during the transfer to adjacent cells (Kwon and Kim 2006). There was an experiment conducted regarding the effect of TGBp1 on assembling the particles and their movement. Particles, which contained TGBp1 on one virion tail, are called STP (single-tailed particles, Fig. 2b) (Karpova et al. 2006). The RNA of PVX with STP is a form fit for translation (Karpova et al. 2006), while PVX virions do not have that quality, possibly, TGBp1 associated with virions at early stages of infection cause destabilization of translation. When the virus enters the cell, CP phosphorylation may trigger translation, and then it initiates the virus infection cycle. When PVX spreads cell-tocell, TGBp1 may function as a promoter causing STP transfer to adjacent cells (Atabekov et al. 2000; Rodionova et al. 2003).

Verchot-Lubicz (2005) distinguished events in PVX cell-to-cell movement. During early events it is TGBp1 that sets inside PD (Verchot-Lubicz 2005) and not capsid protein as it was assumed before (Rouleau et al. 1995; Oparka et al. 1999). TGBp1 can increase the size exclusion limit. Some TGBp1 molecules move to neighboring cells, where they blocked RNA silencing ahead of virus infection. Other molecules TGBp1 bind with TGBp2 or TGBp3 and formed in that way complexes move across PDs. TGBp1/TGBp2 or TGBp1/TGBp3 complexes may transfer to adjacent cells where they act as a blockage of silencing and other types of host defense response. It may play an important role in initiating virus transport. In neighboring cells, TGBp2 and TGBp3 bind with ER membrane near PD, which creates a docking complex (Fig. 2a). In the middle events, TGBp1-PVX virions or ribonucleoprotein complexes move across PD. The ribonucleoprotein complex containing TGBp1, capsid protein and viral RNA moves across PDs. Basing on structural analysis of TGBp1PVX complex described by Kiselyova et al. (2003), we still do not know its nature. In the late events, TGBp1-PVX or TGBp1-CP-RNA is associated with ER membrane by adjacent cell docking complex. The complex is built from joined together oligomers TGBp1 in TGBp2 and TGBp3. The TGBp1 presence in oligomers form unwinds PVX virions or the ribonucleoprotein complexes, making viral RNA available for translation (Fig. 2b) (Verchot-Lubicz 2005). Virus replication in the neighboring cell follows translation. This membrane-bound movement complex also might be a center for replication of viral RNA following translation. Some free CP displaces TGBp1 within the PD, restoring the $\mathrm{PD}$ to its resting state. TGBp1 might be recycled to provide either more round of RNA transport or to spread beyond the infection front suppressing RNA silencing.

This model for Potexvirus links viral RNA translation and counter defense with virus transport. These models suggest that PD transport of viral nucleic acids does not occur in isolation from other events in the infection cycle. What happens to the nucleic acid after it moves through the PD might determine the mechanisms by which it is transported from cell to cell.

\section{TGB cooperating system}

TGBp1 is a multifunctional protein needed for cell-to-cell movement of Potexvirus. TGBp1 provokes PD expansion (guiding the transfer of the virus and other molecules between cells). It shows the activity of RNA helicase and it may also be a component of vRNP complex (Yang et al. 2000; Howard et al. 2004). Moreover, TGBp1 is a suppressor of RNA silencing (Voinnet et al. 2000). It was proposed that TGBp1 interacts with RDR6, which participates in the production of short interfering RNA (siRNA) (Qu et al. 2005; Schwach et al. 2005; Xie and Guo 2006). RDR6, DCL4 and HEN1 are agents required for initiating and maintaining the silencing of virus-induced gene in developmental tissues. DCL4 produces $21 \mathrm{nt}$ viral siRNA, amplified by RDR6 (Dunoyer et al. 2005; Blevins et al. 2006; Deleris et al. 2006). TGBp1 mutations, which block its activity also stop virus transport, which indicates that these processes are associated (Bayne et al. 2005). TGBp1 Potexvirus blocks $21 \mathrm{nt}$ siRNA amplification or it inhibits RDR6-this question still remains unclear. However, its role as a silencing suppressor protects the replicating virus from being a target for RNA silencing.

TGBp2 and TGBp3 Potexvirus are ER-binding proteins. The analysis of amino acidic sequence showed that TGBp2 has 2 transmembrane domains and TGBp3 one N-terminal domain (Krishnamurthy et al. 2003; Mitra et al. 2003). Mutation disrupting membrane associations of these proteins also inhibit virus movement, indicating that ER association is important (Krishnamurthy et al. 2003). GFP to TGBp3 fusion and introducing a construct into a PVX genome in protoplasts of inoculated plants resulted in constructs fluorescence mainly in small granular vesicles and in ER (Ju et al. 2005). Granular vesicles accumulate on actin filaments, which suggest that they may move along the cytoskeleton to PD. Studies conducted with the use of an electron microscope showed that these are vesicles from ER induced by GFP-TGBp2. Vesicular structures 
Fig. 2 Potato virus $X$ local transport. a Early stage: preludium to virus move. The TGBp1-PVX moves itself and is able to increase SEL. TGBp1 binds TGBp2 or TGBp3 and forms complexes move across PD. These complexes may transfer to adjacent cells. They initiate virus transport. TGBp2 withTGBp3 bind ER

membranes and create docking complexes. b Late stage: virions or RNP complexes moves across PD. The TGBp1-PVX virons or RNP complexes (TGBp1 + CP + vRNA) are associated with ER membranes by docking complexes. TGBp1 presence in oligomers form unwind PVX virions or RNP complexes, making vRNA available for translation a

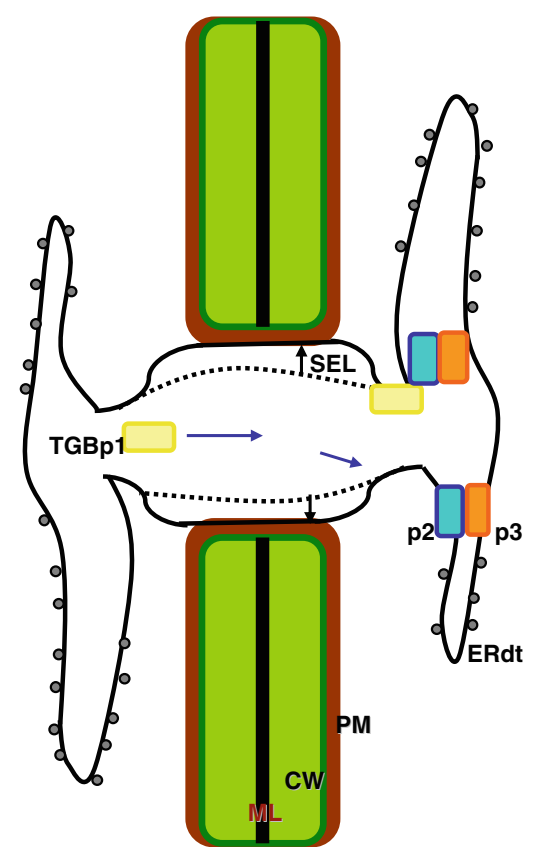

b

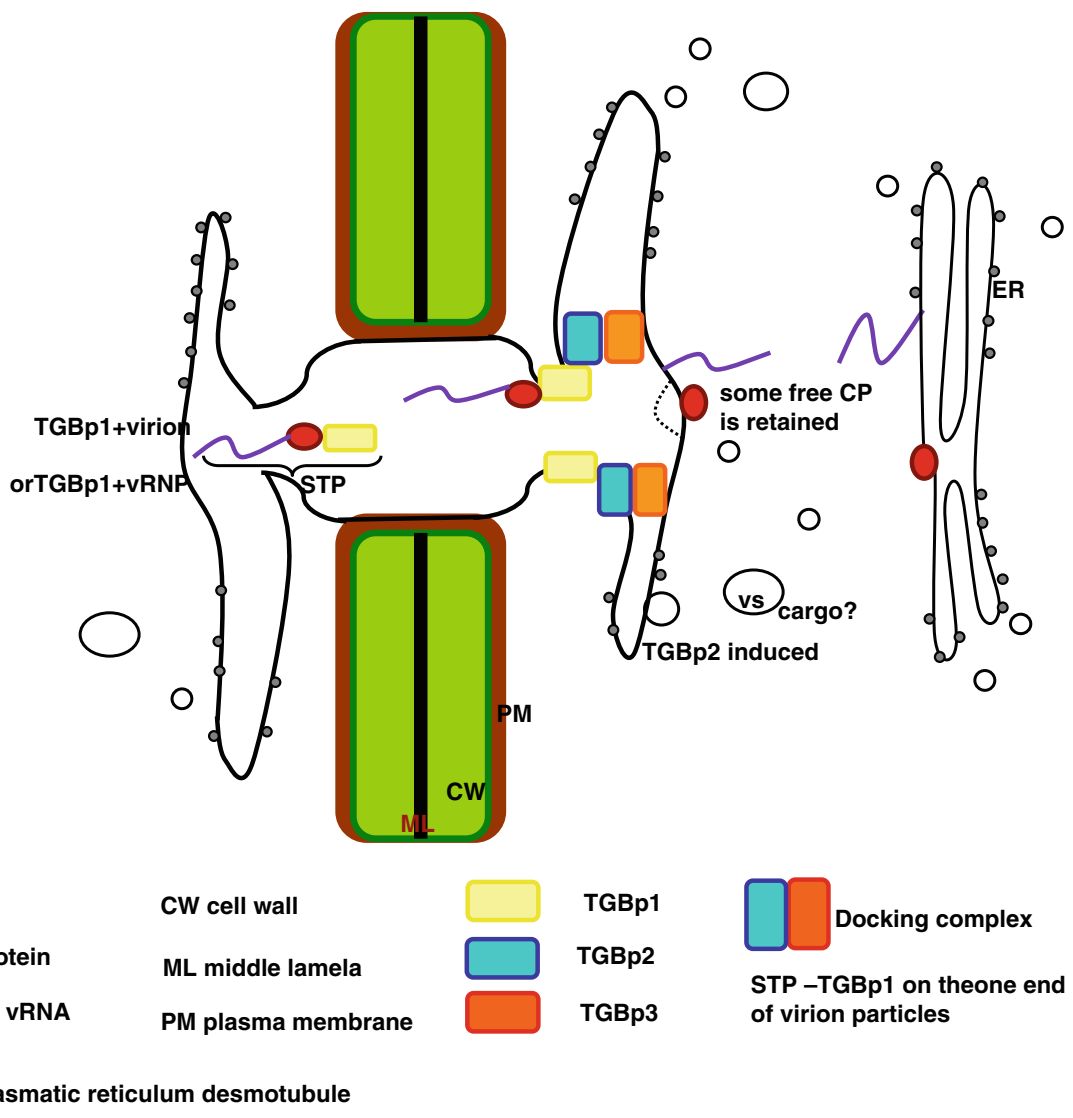

contained ribosomes, were immunoactive from GFP and BiP antigens (chaperon protein present in ER). Deletion of conservative amino acids in TGBp2 central region (located between 2 transmembrane domains) blocked the accumulation of GFP-TGBp2 in small, granular vesicles and inhibited cell-to-cell movement of the virus (Ju et al. 2007). Such data indicate that vesicular structures induced by TGBp2 PVX are necessary for virus movement (Ju et al. 2007). In tobacco plants, where the construct GFP-TGBp3 was subject to expression, fluorescence was connected 
mainly with ER (Krishnamurthy et al. 2003). When plasmid containing GFP-TGBp3 was subject to co-expression with PVX, fluorescence was observed in granular vesicles, similar to those induced by TGBp2 (Schepetilnikov et al. 2005). It is possible that TGBp2 can direct TGBp3 to the same ER vesicles during viral infection. Studies prove that TGBp2 and TGBp3 sometimes coexist (Zamyatnin et al. 2002). So far there has not been provided any data which would show whether TGBp2-related vesicles contain TGBp1, vRNA, CP or virus-like particles. In addition, there is no direct evidence that would confirm a direct mutual interaction between TGB and CP PVX. There is scarce evidence to support the idea that all four proteins and vRNA form a transport-complex. The more we learn about the role of particular proteins, the more questions arise about how such different types of activity can cooperate in promoting cell-to-cell trafficking of viral RNA.

Some scholars suggest that TGBp1, TGBp2, and TGBp3 form a membrane-associated complex, which moves along ER and across PD. Another view is that the activity of Potexvirus transport proteins and $\mathrm{CP}$ can rather cooperate in time and space then directly form a single complex (Verchot-Lubicz 2005). Data that CP is accumulated inside PD and that TGBp1 gates PD suggest that these two proteins can act independently of TGBp2 and TGBp3 in order to regulate changes in PD aperture (Verchot-Lubicz et al. 2007). Virions or viral RNA can be transported to PD during later stages of infection inside the cell. If TGBp2 and TGBp3 coordinate the transport of TGBp1-CP-vRNA complex along ER into PD (Morozov and Solovyev 2003; Lucas 2006), available data illustrating that vesicles inducing TGBp2 PVX are vital for cell-to-cell transfer (Ju et al. 2007) bring to mind a question about the contents of these vesicles. Do they transfer infection agents from cell to cell? Model in which vesicles transport viral RNA to $\mathrm{PD}$ seems to be rather in opposition to the theory on the movement of TGBp1-CP-vRNA complex along ER to PD. It is also possible that TGBp2-induced vesicles play a role in modulating the ER stress responses (Ju et al. 2005) or other events in the virus life cycle, thereby enabling virus cell-to-cell movement.

\section{Potyviruses components of transport networks}

The genus Potyvirus doesn't code specific movement proteins. The Potyvirus movement involves viral proteins that perform additional roles in the virus life cycle (Carrington et al. 1996). The Potyvirus are positive-strand RNA viruses that encode ten mature proteins through a polyprotein expression strategy (Riechmann et al. 1992). Cell-to-cell transport requires an assembly component capsid protein (Dolja et al. 1994, 1995) suggesting that intercellular transport involves virion formation. The Potyvirus are classified as secondary movement type (II) regarding the engagement of $\mathrm{CP}$ protein in cell-to-cell transport and a need for several additional proteins (in case of PVY, two) to act as MP (see Table 1, Scholthof 2004).

The potyviral CP is a three-domain protein with variable $\mathrm{N}$ - and $\mathrm{C}$-terminal regions exposed and a particle surface and a conserved core domain that interacts with viral RNA (Shukla and Ward 1989). Dolja et al. (1994; 1995) produced mutants in the CP-core region TEV-GUS. All of these were defective in cell-to-cell movement and in virion assembly. This mutational analysis also showed that the $\mathrm{N}$-terminal domain of the $\mathrm{CP}$ has an accessory role in this movement process since mutants with this domain removed slow cell-to-cell movement in inoculated leaves.

Eagles et al. (1994) and Klein et al. (1994) have implicated the CI protein, an RNA helicase required for genome replication, in Potyvirus cell-to-cell movement. In electron microscopy studies CI protein is seen to form aggregates (pinwheels or cylindrical inclusions) in the cytoplasm of infected cells. These inclusions are seen positioned over the plasmodesmatal aperture (Fig. 3) (Revers et al. 1999). Two alanine-scanning mutants (CI-AS) with substitutions affecting the $\mathrm{N}$-terminal region of CI protein TEV (Tobacco etch virus) were defective in intercellular movement (Carrington et al. 1998). Carrington et al. (1998) also suggested that the $\mathrm{N}$-terminal region of CI protein provides a critical replication-independent movement function. The Potyvirus RNA replication requires the helicase-associated activities, while cell-to-cell movement requires a non-replication function involving the $\mathrm{N}$-terminal region and possibly helicase activities. In combination with ultrastructural analyses and genetic data Carrington et al. (1998) results support a model in which Potyvirus CI protein interacts directly with PD and capsid protein within ribonucleoprotein complexes to facilitate Potyvirus cell-tocell movement. Ultrastructural research of tissues at an early stage of infection with immunogold labeling of specific Potyvirus proteins, have supported the role $\mathrm{CI}$ in local transport with cooperation in CP (Rodriguez-Cerezo et al. 1997; Roberts et al. 1998). Observation of young tobacco leaves infected with TVMV (Tobacco vein mottling virus; Rodriguez-Cerezo et al. 1997) or cells during advanced PSbMV (Pea seed-borne mosaic virus) infection in pea cotyledons (Roberts et al. 1998) showed that cytoplasmic inclusions immunolabeled for $\mathrm{CI}$ protein and $\mathrm{CP}$ were attached to the plasma membrane, close to or over the plasmodesmal openings. The plasmodesmal aperture contained CP and also viral RNA during TVMV tobacco infection. Behind PSbMV infection front cytoplasmic inclusions were no longer associated with the cell wall or with CP. At an advanced stage of infection cytoplasmic inclusions accumulated as the characteristic pinwheels in 

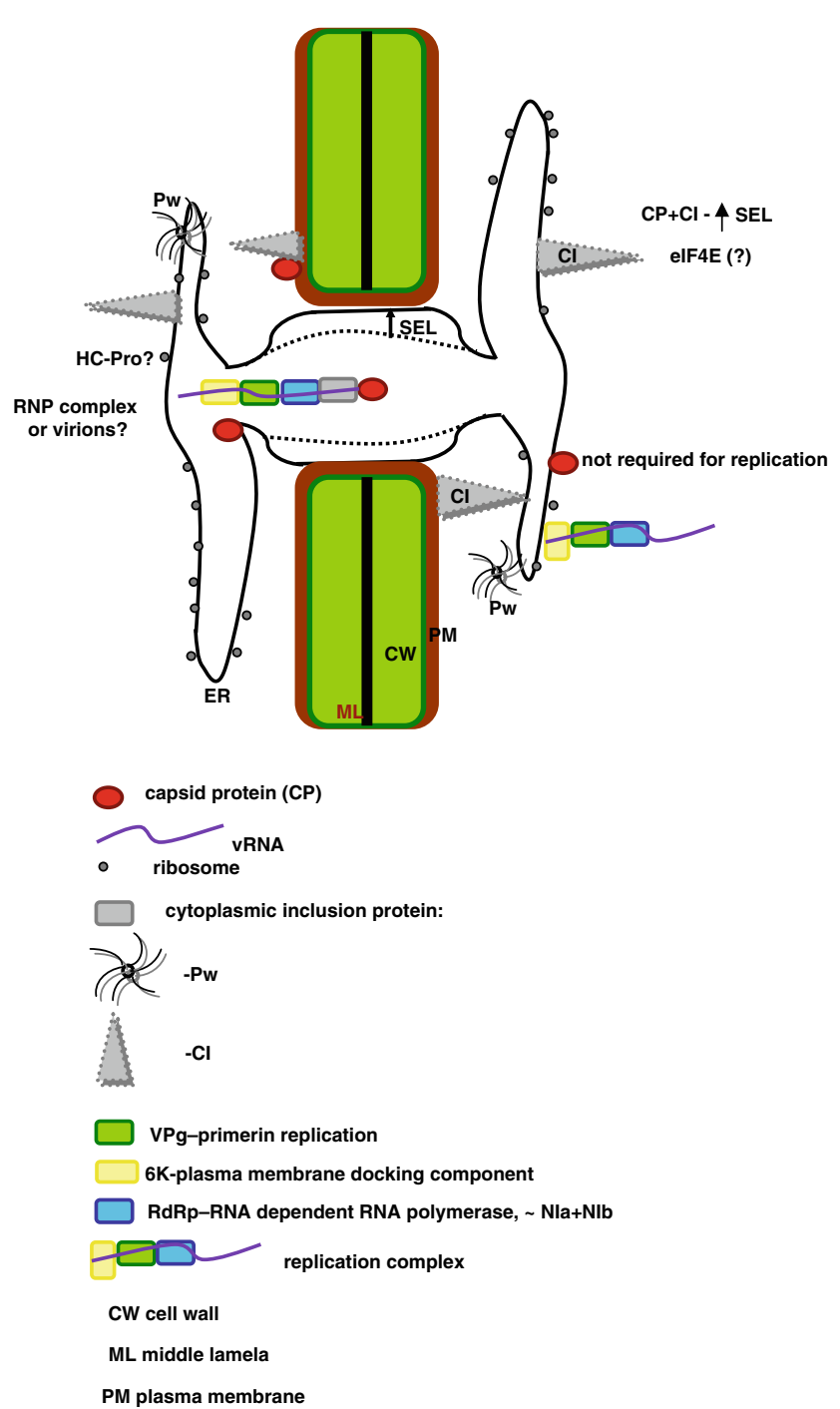

Fig. 3 Potato virus $Y$ cell-to-cell movement. The PVY CP acts as MP. In Potyvirus local transport CI protein cooperates with $\mathrm{CP}$ in SEL increasing and often were attached to palsma membrane, close to PDs. The Potyvirus cytoplasmic inclusions (pinwheels or laminated inclusions) can function to position viral complexes through PDs. The role of the HC-Pro protein is not clear in cell-to-cell transport (probably interact with CP in SEL increasing). Does Potyvirus move as a virions, RNP complex or maybe as a replication complex ?-direct evidence is still lacking. Interacting host components are still not known

the cytoplasm (Roberts et al. 1998). Both studies suggested that Potyvirus cytoplasmic inclusions could function transiently to transfer viral complexes through PD.

Some genetic analyses indicate the involvement of the HC-Pro protein in cell-to-cell transport, but its direct role in this process is not clear (Cronin et al. 1995; Kasschau et al. 1997). The TEV HC-Pro mutant appeared to move from cell-to-cell less efficiently than the native/natural virus (Kasschau et al. 1997), whereas TVMV HC-Pro mutant was unable to spread in inoculated leaves (Klein et al. 1994). HC-Pro proteins together with CP were shown to increase plasmodesmal SEL and to promote viral RNA movement from cell to cell, whereas CI and NIa proteins did not induce these effects. These studies show that at least two potyviral proteins, CI and CP, cooperate and could be considered movement proteins. From Carrington's model (1998) CI protein may direct intracellular translocation of the viral transport complex, which includes the capsid protein. CP may interact with PD to increase the SEL. CI protein may function to position the viral complex for translocation through CI structures into the PD and to adjacent cells (Fig. 3) (Revers et al. 1999). Strong correlation between virion assembly and for cell-to-cell movement (Dolja et al. 1994, 1995) and also fibrillar material (similar to PSbMV particles) may be taken as an indication that Potyviruses move intracellular as a virions, but direct evidence is still lacking.

It is interesting that Potyvirus is the biggest known plants virus genus, but the knowledge about interacting host components is not clear. Recently, a potential link between virus accumulation and cell-to-cell movement was identified when the eukaryotic translocation factors eIF4E and $\operatorname{eIF}$ (iso)4E were shown to aid in virus cell-to-cell movement (Gao et al. 2004). These observations correspond with earlier studies where plant mutants with eIF4E exhibit limited virus spread (Arroyo et al. 1996). It has been speculated that Potyvirus intracellular movement may occur via an interaction of eIF4E with eIF4G, which then binds microtubules (Lellis et al. 2002).

\section{Conclusion}

It is important to realize that the host proteins may function in the virus infection process in translocation and/or replication and also in cell-to-cell movement (Nelson and Citovsky 2005). Viruses reveal different movement strategies with specific viral and host components interacting in efficient, functional transport events. Most of the viruses are transported as nucleoprotein complexes, others as virions, so taxonomically different viruses can use similar strategies, but some use more than one. The inherent flexibility of plant viruses to adjust the nature of the transported material to specific circumstances a property, that is probably of key importance for adaptation to new host. In our review several processes are described, for which the precise mechanism is unknown, therefore many fascinating challenge still lie ahead. Probably studies of the functional role of identified host factors could have predominant influence on plant virus movement. This knowledge should substantially improve our understanding of how the virus and the host partner together cooperate in movement process. 
Open Access This article is distributed under the terms of the Creative Commons Attribution Noncommercial License which permits any noncommercial use, distribution, and reproduction in any medium, provided the original author(s) and source are credited.

\section{References}

Arroyo R, Soto MJ, Martinez-Zapater JM, Ponz F (1996) Impaired cell-to-cell movement of Potato virus $Y$ in pepper plants carrying the $\mathrm{y}^{\mathrm{a}}\left(p r 2^{1}\right)$ resistance gene. Mol Plant Microbe Interact 9:314318

Asurmendi S, Berg RH, Koo JC, Beachy RN (2004) Coat protein regulates formation of replication complexes during tobacco mosaic virus infection. Proc Natl Acad Sci USA 101:14151420

Atabekov JG, Malyshenko SI, Morozov SY, Taliansky ME, Solovyev AG, Agranovsky AA, Shapka NA (1999) Identification and study of tobacco mosaic virus movement function by complementation tests. Philos Trans R Soc Lond Biol Sci 354:629-635

Atabekov JG, Rodionova NP, Karpova OV, Kozlovsky SV, VYu Poljakov (2000) The movement protein-triggered in situ conversion of potato virus $\mathrm{X}$ virion RNA from nontraslatable into a translatable form. Virology 271:259-263

Baluska F, Samaj J, Napier R, Volkmann D (1999) Maize calreticulin localizes preferentially to plasmodesmata in root apex. Plant $\mathrm{J}$ 19:481-488

Bayne EH, Rakitina DV, Morozov SY, Baulcombe DC (2005) Cellto-cell movement of potato potexvirus $\mathrm{X}$ is dependent on suppression of RNA silencing. Plant J 44:471-482

Blackman LM, Overall RL (1998) Immunolocalisation of the cytoskeleton to plasmodesmata of Chara corallina. Plant $\mathrm{J}$ 14:733-741

Blevins T, Rajeswaran R, Shivaprasad PV, Beknazariants D, Si-Ammour A, Park HS, Vazquez F, Robertson D, Meins F Jr, Hohn T, Pooggin MM (2006) Four plant Dicers mediate viral small RNA biogenesis and DNA virus induced silencing. Nucleic Acids Res 34:6233-6246

Boevink P, Oparka KJ (2005) Virus-host interactions during movement processes. Plant Physiol 138:1815-1821

Boyko V, Ferralli J, Ashby J, Schellenbaum P, Heinlein M (2000) Function of microtubules in intercellular transport of plant virus RNA. Nat Cell Biol 2:826-832

Brill LM, Nunn RS, Kahn TW, Yeager M, Beachy RN (2000) Recombinant tobacco mosaic virus movement protein is an RNA-binding, alpha-helical membrane protein. Proc Natl Acad Sci USA 97:7112-7117

Carrington JC, Kasschau KD, Mahajan SK, Schaad MC (1996) Cellto-cell and long distance transport of viruses in plants. Plant Cell 8:1669-1681

Carrington JC, Jensen PE, Schaad MC (1998) Genetic evidence for an essential role for potyvirus CI protein in cell-to-cell movement. Plant J 14:393-400

Chen X-Y, Kim J-Y (2006) Transport of macromolecules through plasmodesmata and the phloem. Physiol Plant 126:560-571

Chen MH, Sheng J, Hind G, Handa A, Citovsky V (2000) Interaction between the tobacco mosaic virus movement protein and host cell pectin methylesterases is required for viral cell-to-cell movement. EMBO J 19:913-920

Chen M-H, Tian G-W, Gafni Y, Citovsky V (2005) Effects of calreticulin on viral cell-to-cell movement. Plant Physiol 138:1866-1876

Citovsky V, Zambryski PC (1993) Transport of nucleic acids through membrane channels: snaking through small holes. Annu Rev Microbiol 47:167-197
Citovsky V, Knorr D, Schuster G, Zambryski P (1990) The P30 movement protein of Tobacco mosaic virus is a single-stranded nucleic acid binding protein. Cell 60:637-647

Citovsky V, Wong ML, Shaw A, Prasad BVV, Zambryski P (1992) Visualization and characterization of tobacco mosaic virus movement protein binding to single-stranded nucleic acids. Plant Cell 4:397-411

Cronin S, Verchot J, Haldeman-Cahill R, Schaad MC, Carrington JC (1995) Long-distance movement factor: a transport function of the potyvirus helper component proteinase. Plant Cell 7:549-559

Curin M, Ojangu EL, Trutnyeva K, Ilau B, Truve E, Waigmann E (2007) MPB2C, a microtubule-associated plant factor, is required for microtubular accumulation of Tobacco mosaic virus movement protein in plants. Plant Physiol 143:801-811

Deleris A, Gallego-Bartolome J, Bao J, Kasschau KD, Carrington JC, Voinnet $\mathrm{O}$ (2006) Hierarchical action and inhibition of plant Dicer-like proteins in antiviral defense. Science 313:68-71

Ding B, Turgeon R, Parthasarathy MV (1992) Substructure of freezesubstituted plasmodesmata. Protoplasma 169:28-41

Dolja VV, Haldeman R, Robertson NL, Dougherty WG, Carrington JC (1994) Distinct functions of capsid protein in assembly and movement of tobacco etch potyvirus in plants. EMBO $\mathrm{J}$ 13:1482-1491

Dolja VV, Haldeman-Cahill R, Montgomery AE, Vandenbosch KA, Carrington JC (1995) Capsid protein determinants involved in cell-to-cell and long distance movement of tobacco etch potyvirus. Virology 206:1007-1016

Dorokhov YL, Makinen K, Frolova OY, Merits A, Saarinen J, Kalkkinen N, Atabekov JG, Saarma M (1999) A novel function for a ubiquitous plant enzyme pectin methylesterase: the hostcell receptor for the tobacco mosaic virus movement protein. FEBS Lett 461:223-228

Dunoyer P, Himber C, Voinnet O (2005) DICER-LIKE 4 is required for RNA interference and produces the 21-nucleotide small interfering RNA component of the plant cell-to-cell silencing signal. Nat Genet 37:1356-1360

Eagles RM, Balmori-Melián E, Beck DL, Gardner RC, Forster RL (1994) Characterization of NTPase, RNA-binding and RNAhelicase activities of the cytoplasmic inclusion protein of tamarillo mosaic potyvirus. Eur J Biochem 224:677-684

Esau K, Cronshaw J (1967) Tubular components in cells of healthy and tobacco mosaic virus-infected Nicotiana. Virology 33:26-35

Fridborg I, Grainger J, Page A, Coleman M, Findlay K, Angell S (2003) TIP, a novel host factor linking callose degradation with the cell-to-cell movement of Potato virus X. Mol Plant Microbe Interact 16:132-140

Gaffe J, Tiznado ME, Handa AK (1997) Characterization and functional expression of a ubiquitously expressed tomato pectin methylesterase. Plant Physiol 114:1547-1556

Gao Z, Johansen E, Eyers S, Thomas CL, Noel Ellis TH, Maule AJ (2004) The potyvirus recessive resistance gene, sbm1, identifies a novel role for translation initiation factor eIF4E in cell-to-cell trafficking. Plant J 40:376-385

Gibbs AJ (1976) Viruses and plasmodesmata. In: Gunning BES, Robards AW (eds) Intercellular communication in plants: studies on plasmodesmata. Springer-Verlag, Berlin, pp 149-164

Gillespie T, Boevink P, Haupt S, Roberts AG, Toth R, Vantine T, Chapman S, Oparka KJ (2002) Functional analysis of a DNA shuffled movement protein reveals that microtubules are dispensable for the cell-to-cell movement of Tobacco mosaic virus. Plant Cell 14:1207-1222

Guenoune-Gelbart D, Elbaum M, Sagi G, Levy A, Epel BL (2008) Tobacco mosaic virus (TMV) replicase and movement protein function synergistically in facilitating TMV spread by lateral diffusion in the plasmodesmal desmotubule of Nicotiana benthamiana. Mol Plant Microbe Interact 21:335-345 
Haywood V, Kragler F, LucasW J (2002) Plasmodesmata: pathways for protein and ribonucleoprotein signaling. Plant Cell 14:S303S 325

Heinlein M, Epel BL (2004) Macromolecular transport and signaling through plasmodesmata. Int Rev Cytol 235:93-164

Heinlein M, Epel BL, Padgett HS, Beachy RN (1995) Interaction of tobamovirus movement proteins with the plant cytoskeleton. Science 270:1983-1985

Heinlein M, Padgett HS, Gens JS, Pickard BG, Casper SJ, Epel BL, Beachy RN (1998) Changing patterns of localization of the Tobacco mosaic virus movement protein and replicase to the endoplasmic reticulum and microtubules during infection. Plant Cell 10:1107-1120

Hofmann C, Niehl A, Sambade A, Steinmetz A, Heinlein M (2009) Inhibition of tobacco mosaic virus movement by expression of an actin-binding protein. Plant Physiol 149:1810-1823

Howard AR, Heppler ML, Ju HJ, Krishnamurthy K, Payton ME, Verchot-Lubicz J (2004) Potato virus X TGBp1 induces plasmodesmata gating and moves between cells in several host species whereas CP moves only in $N$. benthamiana leaves. Virology 328:185-197

Huisman MJ, Linthorst HJ, Bol JF, Cornelissen JC (1988) The complete nucleotide sequence of potato virus $\mathrm{X}$ and its homologies at the amino acid level with various plus-stranded RNA viruses. J GenVirol 69:1789-1798

Ju HJ, Samuels TD, Wang YS, Blancaflor E, Payton M, Mitra R, Krishnamurthy K, Nelson RS, Verchot-Lubicz J (2005) The potato virus $\mathrm{X}$ TGBp2 movement protein associates with endoplasmic reticulum-derived vesicles during virus infection. Plant Physiol 138:1877-1895

Ju HJ, Brown JE, Ye CM, Verchot-Lubicz J (2007) Mutations in the central domain of potato virus $\mathrm{X}$ TGBp2 eliminate granular vesicles and virus cell-to-cell trafficking. J Virol 81:1899-1911

Karpova OV, Ivanov KI, Rodionova NP, YuL Dorokhov, Atabekov JG (1997) Nontranslatability and dissimilar behavior in plants and protoplasts of viral RNA and movement protein complexes formed in vitro. Virology 230:11-21

Karpova OV, Rodionova NP, Ivanov KI, Kozlovsky SV, Dorokhov YL, Atabekov JG (1999) Phosphorylation of tobacco mosaic virus movement protein abolishes its translation repressing ability. Virology 261:20-24

Karpova OV, Zayakina OV, Arkhipenko MV, Sheval EV, Kiselyova OI, Poljakov VY, Yaminsky IV, Rodionova NP, Atabekov JG (2006) Potato virus X RNA-mediated assembly of single-tailed ternary 'coat protein-RNA-movement protein' complexes. J Gen Virol 87:2731-2740

Kasschau KD, Cronin S, Carrington JC (1997) Genome amplification and long-distance movement functions associated with the central domain of tobacco etch potyvirus helper componentproteinase. Virology 228:251-262

Kawakami S, Watanabe Y, Beachy RN (2004) Tobacco mosaic virus infection spreads cell-to-cell as intact replication complexes. Proc Natl Acad Sci USA 101:6291-6296

Kiselyova OI, Yaminsky IV, Karger EM, Frolova OY, Dorokhov YL, Atabekov JG (2001) Visualization by atomic force microscopy of tobacco mosaic virus movement protein-RNA complexes formed in vitro. J Gen Virol 82:1503-1508

Kiselyova OI, Yaminsky IV, Karpova OV, Rodionova NP, Kozlovsky SV, Arkhipenko MV, Atabekov JG (2003) AFM study of potato virus $\mathrm{X}$ disassembly induced by movement protein. J Mol Biol 332:321-325

Klein PG, Klein RR, Rodríguez-Cerezo E, Hunt AG, Shaw JG (1994) Mutational analysis of the tobacco vein mottling virus genome. Virology 204:759-769

Koonin EV, Mushegian AR, Ryabov EV, Dolja VV (1991) Diverse groups of plant RNA and DNA viruses share related movement proteins that may possess chaperone-like activity. J Gen Virol 72:2895-2903

Kragler F, Curin M, Trutnyeva K, Gansch A, Waigmann E (2003) MPB2C, a microtubule-associated plant protein binds to and interferes with cell-to-cell transport of Tobacco mosaic virus movement protein. Plant Physiol 132:1870-1883

Krishnamurthy K, Heppler M, Mitra R, Blancaflor E, Payton M, Nelson RS, Verchot-Lubicz J (2003) The Potato virus X TGBp3 protein associates with the ER network for virus cell-to-cell movement. Virology 309:135-151

Kwon SJ, Kim KH (2006) The SL1 stem-loop structure at the 5'-end of potato virus $\mathrm{X}$ RNA is required for efficient binding to host proteins and for viral infectivity. Mol Cells 21:63-75

Kwon SJ, Park MR, Kim KW, Plante CA, Hemenway CL, Kim KH (2005) Cis-acting sequences required for coat protein binding and in vitro assembly of Potato virus X. Virology 334:83-97

Lellis AD, Kasschau KD, Whitham SA, Carrington JC (2002) Lossof-susceptibility mutants of Arabidopsis thaliana reveal an essential role for eIF(iso)4E during potyvirus infection. Curr Biol 12:1046-1051

Lin J-W, Chiu H-N, Chen I-H, Chen T-C, Hsu Y-H, Tsai C-H (2005) Structural and functional analysis of the cis-acting elements required for plus-strand RNA synthesis of Bamboo mosaic virus. J Virol 79:9046-9053

Lippincott-Schwartz J, Roberts TH, Hirschberg K (2000) Secretory protein trafficking and organelle dynamics in living cells. Annu Rev Cell Dev Biol 16:557-589

Liu JZ, Blancaflor EB, Nelson RS (2005) The tobacco mosaic virus 126-kilodalton protein, a constituent of the virus replication complex, alone or within the complex aligns with and traffics along microfilaments. Plant Physiol 138:1853-1865

Lough TJ, Lee RH, Emerson SJ, Forster RL, Lucas WJ (2006) Functional analysis of the 5' untranslated region of potexvirus RNA reveals a role in viral replication and cell-to-cell movement. Virology 351:455-465

Lucas WJ (1995) Plasmodesmata: intercellular channels for macromolecular transport in plants. Curr Opin Cell Biol 7:673-680

Lucas WJ (2006) Plant viral movement proteins: agents for cell-tocell trafficking of viral genomes. Virology 344:169-184

Lucas WJ, Lee JY (2004) Plasmodesmata as a supracellular control network in plants. Nat Rev Mol Cell Biol 5:712-726

Lucas WJ, Ding B, van der Schoot C (1993) Plasmodesmata and the supracellular nature of plants. New Phytol 125:435-476

Mas P, Beachy RN (1999) Replication of tobacco mosaic virus on endoplasmic reticulum and role of the cytoskeleton and virus movement protein in intracellular distribution of viral RNA. J Cell Biol 147:945-958

McLean BG, Zupan J, Zambryski PC (1995) Tobacco mosaic virus movement protein associates with the cytoskeleton in tobacco cells. Plant Cell 7:2101-2114

Michalak M, Corbett EF, Mesaeli N, Nakamura K, Opas M (1999) Calreticulin: one protein, one gene, many functions. Biochem J 344:281-292

Miller ED, Plante CA, Kim KH, Brown JW, Hemenway C (1998) Stem-loop structure in the 5 , region of potato virus $\mathrm{X}$ genome required for plus-strand RNA accumulation. J Mol Biol 284:591-608

Miller ED, Kim KH, Hemenway C (1999) Restoration of a stem-loop structure required for potato virus X RNA accumulation indicates selection for a mismatch and a GNRA tetraloop. Virology 260:342-353

Mitra R, Krishnamurthy K, Blancaflor E, Payton M, Nelson RS, Verchot-Lubicz J (2003) The Potato virus $X$ TGBp2 protein association with the endoplasmic reticulum plays a role in but is not sufficient for viral cell-to-cell movement. Virology $312: 35-48$ 
Morozov SY, Solovyev AG (2003) Triple gene block: modular design of a multifunctional machine for plant virus movement. J Gen Virol 84:1351-1366

Nelson RS, Citovsky V (2005) Plant viruses. Invaders of cells and pirates of cellular pathways. Plant Physiol 138:1809-1814

Oparka KJ (2004) Getting the message across: how do plant cells exchange macromolecular complexes? Trends Plant Sci 9:33-41

Oparka KJ, Roberts AG, Boevink P, Santa Cruz S, Roberts I, Pradel KS, Imlau A, Kotlizky G, Sauer N, Epel B (1999) Simple, but not branched, plasmodesmata allow the nonspecific trafficking of proteins in developing tobacco leaves. Cell 97:743-754

Peremyslov VV, Hagiwara Y, Dolja VV (1999) HSP70 homolog functions in cell-to-cell movement of a plant virus. Proc Natl Acad Sci USA 96:14771-14776

Qu F, Ye X, Hou G, Sato S, Clemente TE, Morris TJ (2005) RDR6 has a broad-spectrum but temperature-dependent antiviral defense role in Nicotiana benthamiana. J Virol 79:15209-15217

Reichel C, Más P, Beachy RN (1999) The role of the ER and cytoskeleton in plant viral trafficking. Trends Plant Sci 4:458462

Revers F, Le Gall O, Candresse T, Maule AJ (1999) New advances in understanding the molecular biology of plant/potyvirus interactions. Mol Plant Microbe Interact 12:367-376

Riechmann JL, Laín S, García JA (1992) Highlights and prospects of potyvirus molecular biology. J Gen Virol 73:1-16

Roberts IM, Wang D, Findlay K, Maule AJ (1998) Ultrastructural and temporal observations of the potyvirus cylindrical inclusions (Cls) show that the $\mathrm{Cl}$ protein acts transiently in aiding virus movement. Virology 245:173-181

Rodionova NP, Karpova OV, Kozlovsky SV, Zayakina OV, Arkhipenko MV, Atabekov JG (2003) Linear remodeling of helical virus by movement protein binding. J Mol Biol 333:565-572

Rodriguez-Cerezo E, Findlay K, Shaw JG, Lomonossoff GP, Qiu SG, Linstead P, Shank M, Risco C (1997) The coat and cylindrical inclusion proteins of a potyvirus are associated with connections between plant cells. Virology 236:296-306

Rouleau M, Smith RJ, Bancroft JB, Mackie GA (1995) Subcellular immunolocalization of the coat protein of two potexviruses in infected Chenopodium quinoa. Virology 214:314-318

Runions J, Brach T, Kühner S, Hawes C (2006) Photoactivation of GFP reveals protein dynamics within the endoplasmic reticulum membrane. J Exp Bot 57:43-50

Sambade A, Brandner K, Hofmann C, Seemanpillai M, Mutterer J, Heinlein M (2009) Transport of TMV movement protein particles associated with the targeting of RNA to plasmodesmata. Traffic 9:2073-2088

Santa Cruz S, Roberts AG, Prior DAM, Chapman S, Oparka KJ (1998) Cell-to-cell and phloem-mediated transport of potato virus X: the role of virions. Plant Cell 10:495-510

Schepetilnikov MV, Manske U, Solovyev AG, Zamyatnin AA Jr, Schiemann J, Morozov SY (2005) The hydrophobic segment of potato virus $\mathrm{X}$ TGBp3 is a major determinant of the protein intracellular trafficking. J Gen Virol 86:2379-2391

Scholthof KB (2004) Tobacco mosaic virus: a model system for plant biology. Annu Rev Phytopathol 42:13-34

Schwach F, Vaistij FE, Jones L, Baulcombe DC (2005) An RNAdependent RNA polymerase prevents meristem invasion by potato virus $\mathrm{X}$ and is required for the activity but not the production of a systemic silencing signal. Plant Physiol 138:1842-1852

Shukla DD, Ward CW (1989) Identification and classification of potyviruses on the basis of coat protein sequence data and serology. Arch Virol 106:171-200

Tagami Y, Watanabe Y (2007) Effects of brefeldin A on the localization of Tobamovirus movement protein and cell-to-cell movement of the virus. Virology 361:133-140

van Bel AJ (2003) Transport phloem: low profile, high impact. Plant Physiol 131:1509-1510

Verchot-Lubicz J (2005) A new model for cell-to-cell movement of potexviruses. Mol Plant Microbe Interact 18:283-290

Verchot-Lubicz J, Ye CM, Bamunusinghe D (2007) Molecular biology of potexviruses: recent advances. J Gen Virol 88:16431655

Voinnet O, Lederer C, Baulcombe DC (2000) A viral movement protein prevents spread of the gene silencing signal in Nicotiana benthamiana. Cell 103:157-167

Waigmann E, Lucas W, Citovsky V, Zambryski P (1994) Direct functional assay for Tobacco mosaic virus cell-to-cell movement protein and identification of a domain involved in increasing plasmodesmal permeability. Proc Natl Acad Sci USA 91:14331437

Waigmann E, Chen MH, Bachmaier R, Ghoshroy S, Citovsky V (2000) Phosphorylation of tobacco mosaic virus cell-to-cell movement protein regulates viral movement in a host-specific fashion. EMBO J 19:4875-4884

Waigmann E, Ueki S, Trutnyeva K, Citovsky V (2004) The ins and outs of nondestructive cell-to-cell and systemic movement of plant viruses. Crit Rev Plant Sci 23:195-250

Weintraub M, Ragetli HW, Leung E (1976) Elongated virus particles in plasmodesmata. J Ultrastruct Res 56:351-364

Wolf S, Deom CM, Beachy RN, Lucas WJ (1989) Movement protein of Tobacco mosaic virus modifies plasmodesmatal size exclusion limit. Science 246:377-379

Wright KM, Wood NT, Roberts AG, Chapman S, Boevink P, Mackenzie KM, Oparka KJ (2007) Targeting of TMV movement protein to plasmodesmata requires the actin/ER network: evidence from FRAP. Traffic 8:21-31

Xie Q, Guo HS (2006) Systemic antiviral silencing in plants. Virus Res 118:1-6

Yang Y, Ding B, Baulcombe D, Verchot J (2000) Cell-to-cell movement of the $25 \mathrm{~K}$ protein of potato virus $\mathrm{X}$ is regulated by three other viral proteins. Mol Plant Microbe Interact 13:599605

Yokota E, Ueda S, Tamura K, Orii H, Uchi S, Sonobe S, HaraNishimura I, Shimmen T (2009) An isoform of myosin XI is responsible for the translocation of endoplasmic reticulum in tobacco cultured BY-2 cells. J Exp Bot 60:197-212

Zamyatnin AA Jr, Solovyev AG, Sablina AA, Agranovsky AA, Katul L, Vetten HJ, Schiemann J, Hinkkanen AE, Lehto K, Morozov SY (2002) Dual-colour imaging of membrane protein targeting directed by poa semilatent virus movement protein TGBp3 in plant and mammalian cells. J Gen Virol 83:651-662 